\title{
Hanford Facility Contingency Plan
}

\author{
L. N. Sutton
}

A. G. Miskho

Date Published

July 1996

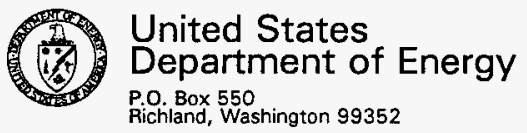

Approved for public release; distribution is unlimited 
LEGAL DISCLAMMER

This report was prepered as an account of work sponsored by an egency of the United States Government. Neither the United States Government nor any agency thereof, nor any of their employees, nor any of their contractors, subcontractors or their employees, makes any warranty, express or implied, or assumes any legal liability or responsibility for the accuracy, completeness, or any third party's use or the results of such use of any information, apparatus, product, or process disclosed, or represents thet its use would not infringe privately owned rights. Reference herein to any specific commercial product, process, or senvice by trade name, trademark, manufacturer, or otherwise, does not necessarily constitute or imply its endorsement, recommendetion, or favoring by the United States Government or any agency thereof or its contractors or subcontractors. The views and opinions of authors expressed herein do not necessarily state or reflect those of the United States Government or any agency thereof.

This report has been reproduced from the best available copy. Available in paper copy and microfiche.

Available to the U.S. Department of Energy

and its contractors from

Office of Scientific and Technical information

P.0. Box 62

Oak Ridge, TN 37831

(615) $576-8401$

Available to the public from the U.S. Department of Commerce National Technical Information Service

5285 Port Royal Roed

Springfield, VA 22161

(703) $487-4650$

Printed in the United Stotet of Americe

DISCLM-1.CHP (1-91) 


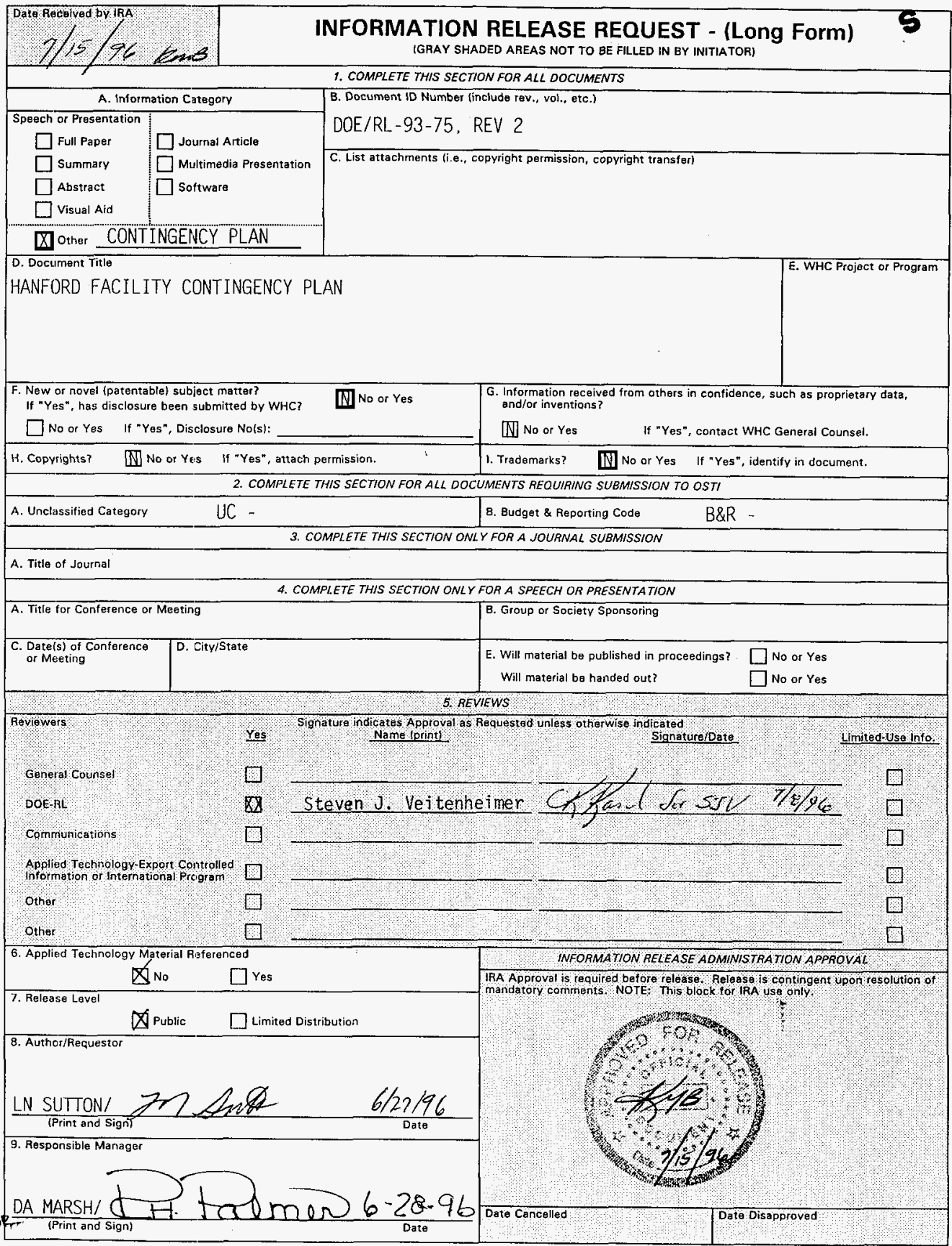


DOE/RL-93-75, REV 2

Document iD Number

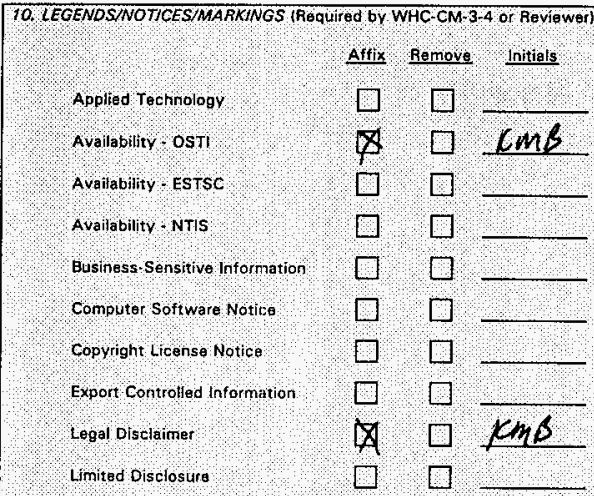

\section{T1 MANDATORY COMMENTS Ulist only mandatory comments here All other comments shall be nade on the document and returned to the author.)}

Official Use onty
Patent Status
Predecisional Information
Programmatic Notice
Proprietary Information
Purpose and Use
Thesis/Dissertation
Tradsmark Disclaimer
Other.

Affix

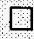

$\square$

Bemove, Initiols

回

$\square$

$\square$

$\square$

$\square$

प

7. 1

1

$\square$

$0 . \square$

$\square$

.

3

12 
DOE $/ R L-93-75$

Rev. 2

Document Tit ie: HANFORD FACILITY CONTINGENCY PLAN

Quality, Safety, and Health

Environmental Assurance, Permits, and Policy

Prepared by

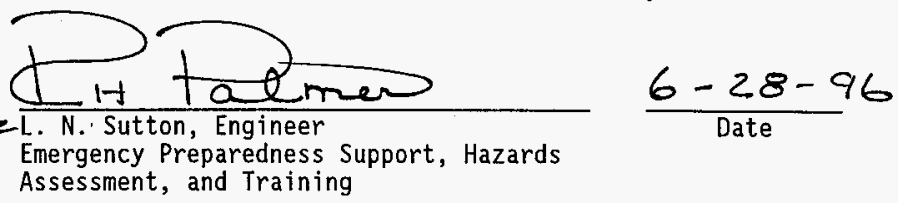

Approved by:

for S.J. Veitenheimer, Director

$\frac{6-28-96}{\text { Date }}$

Quality, Safety, and Health Programs Division

$$
\frac{7-8-96}{\text { Date }}
$$

Environmental Assurance, Permits, and Policy Division

ix 
DOE/RL-93-75

Rev. 2

This page intentionally left blank. 
DOE/RL-93-75

Rev. 2

IMPLEMENTATION NOTICE

DOE/RL-93-75, Hanford Facility Contingency Plan

Revision 2

This document is being issued for use by personnel who are responsible for facilities that are required to meet the contingency planning requirements contained in Washington Administrative Code (WAC) 173-303.

The document replaces Attachment 4, Hanford Facility RCRA Permit, Dangerous Waste Portion.

This document is intended to be used in conjunction with existing TSD unit contingency planning documentation (e.g., building emergency plans) to present a complete picture of contingency planning to regulatory personnel. This document contains descriptions of the Hanford Facility emergency capabilities including equipment, organizations, and standard response actions; descriptions of agreements made with the local agencies; and a description of the occurrence reporting and notification process. 


\section{DOE/RL-93-75}

Rev. 2

This page intentionally left blank. 
DOE $/ R L-93-75$

Rev. 2

HANFORD FACILITY CONTINGENCY PLAN

CONTENTS

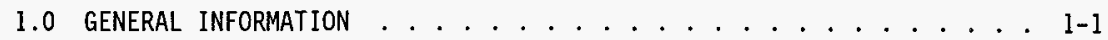

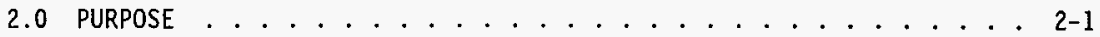

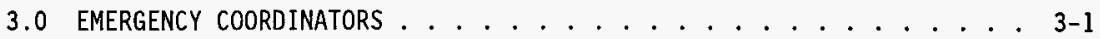

4.0 IMPLEMENTATION OF THE CONTINGENCY PLAN ............ . 4-1

5.0 INCIDENT RESPONSE . . . . . . . . . . . . . . 5-1

5.1 INCIDENT GENERIC RESPONSES .............. . . 5-1

5.1 .1 Discoverer.............. . . 5-1

5.1.2 Single Point-of-Contact ......... 5-2

5.1.3 Emergency Coordinator (or al ternate) ....... 5-2

5.1.4 Identification of Hazardous Substances and Dangerous

Waste and Assessment of Hazards . . . . . . . 5-3

5.1 .5 Incident Classification ............ . . 5-3

5.1.6 Protective Actions . . . . . . . . . . . . . 5-4

5.2 RESPONSE TO MINOR SPILLS OR RELEASES AT TSD UNITS AND OTHER

BUILDINGS . . . . . . . . . . . . . . . . . . .

5.3 RESPONSE TO MAJOR SPILLS OR RELEASES AT TSD UNITS OR OTHER

5.3.1 Discoverer . . . . . . . . . . . . . . . 5-6

5.3.2 Single Point-of-Contact . . . . . . . . . . . 5-7

5.3.3 Emergency Coordinator .............. 5-7

5.3.4 Hanford Fire Department Response

to Major or Unknown Spills ......... 5-8

5.4 RESPONSE TO FIRE . . . . . . . . . . . 5-10

5.5 UNUSUAL, IRRITATING, OR STRONG ODORS . . . . . . . . 5-11

5.6 RESPONSE TO CONTAINER SPILLS OR LEAKS . . . . . . . . . . 5-11

5.7 RESPONSE TO TRANSPORTATION INCIDENTS . . . . . . . . 5-12

5.7.1 Discoverer. . . . . . . . . . . . . . . 5-12

5.7.2 Initial Responder Actions ............ . 5-13

5.7.3 Emergency Coordinator ........... . 5-14

5.8 DAMAGED, UNACCEPTABLE SHIPMENTS .......... . . 5-15

5.9 PREVENTION OF RECURRENCE OR SPREAD $\ldots \ldots$. . . . . . . . . 5-15
OF FIRES, EXPLOSIONS, OR RELEASES . . . . .

6.0 TERMINATION OF EVENT, INCIDENT RECOVERY,
AND RESTART OF OPERATIONS .............. 6-1

6.1 TERMINATION OF EVENT . . . . . . . . . . . . . . . 6-1

6.2 INCIDENT RECOVERY AND RESTART OF OPERATIONS . . . . . . . 6-1

6.3 INCOMPATIBLE WASTE . . . . . . . . . . . . 6-1

6.4 POST-EMERGENCY EQUIPMENT MAINTENANCE AND DECONTAMINATION : . . 6-2 
7.1 HANFORD FACILITY EMERGENCY CENTERS

7.2 COMMUNICATIONS EQUIPMENT . . . . . . . . . . . . . . . 7-1

7.3 FIRE CONTROL EQUIPMENT ................. 7-1

7.4 PERSONAL PROTECTIVE EQUIPMENT ................ . . 7 . .

7.5 SPILL CONTROL AND CONTAINMENT SUPPLIES . . . . . . . . . . . 7-4

7.6 HANFORD SITE EMERGENCY ORGANIZATIONS . . . . . . . . . . . . . . $7-4$

8.0 COORDINATION AGREEMENTS . . . . . . . . . . . . . . 8-1

8.1 LOCAL, STATE, AND FEDERAL AUTHORITIES . . . . . . . . . 8-1

8.2 HANFORD FIRE DEPARTMENT MUTUAL AID . . . . . . . . . . . . 8-1

8.3 MEDICAL AND FIRST AID . . . . . . . . . . . . . . . . 8-1

8.4 AMBULANCE SERVICE . . . . . . . . . . . . . . . . . . . $8-2$

8.5 UNIFIED DOSE ASSESSMENT CENTER . . . . . . . . . . . . . . . . 8 -2

8.6 HANFORD PATROL/BENTON COUNTY SHERIFF . . . . . . . . . . . . . 8-2

8.7 ALERTING OF PERSONNEL ON THE COLUMBIA RIVER . . . . . . . . . . $8-2$

8.8 METEOROLOGICAL INFORMATION .............. 8 . .

9.0 REQUIRED REPORTS ... . . . . . . . . . . . . . . . . . 9-1

9.I ASSESSMENT REPORT TO ECOLOGY AND GOVERNMENT

OFFICIAL OR NATIONAL RESPONSE CENTER . . . . . . . . . . 9-1

9.2 WRITTEN REPORT TO ECOLOGY . . . . . . . . . . . . . . . . . . . 9-1

9.3 OCCURRENCE REPORTING . . . . . . . . . . . . . . . . . . 9-2

9.3.I Emergency Event Reporting . . . . . . . . . . . . . . 9-2

9.3.2 Unusual Occurrence Reporting . . . . . . . . . . . . . 9-2

9.3.3 Offnormal Event Reporting . . . . . . . . . . . 9-3

10.0 CONTINGENCY PLAN LOCATION . . . . . . . . . . . . . . . 10-1

11.0 REFERENCES ......................... . . . . . . . . . 
DOE /RL-93-75

Rev. 2

\section{LIST OF FIGURES}

1. Hanford Facility Evacuation Routes ........... . 5-5

2. Locations of the Fire Stations on the Hanford Facility .....

\section{LIST OF TABLES}

1. Emergency Centers ................. 7-2

2. Hanford Facility Alarm Systems ............ . 7-3

3. Fire Department Equipment List . . . . . . . . . . 7-5 
DOE/RL-93-75

Rev. 2

This page intentionally left blank. 
DOE/RL-93-75

Rev. 2

\subsection{GENERAL INFORMATION}

The Hanford Facility is defined as a single Resource Conservation and Recovery Act (RCRA) of 1976 facility, identified by the EPA/State Identifjcation Number WA7890008967, that consists of over 60 treatment, storage, and/or disposal (TSD) units conducting dangerous waste management activities. The Hanford Facility consists of the contiguous portion of the Hanford Site that contains these TSD units and, for the purposes of RCRA, is owned and operated by the U.S. Department of Energy (excluding lands north and east of the Columbia River, river islands, lands owned or used by the Bonneville Power Administration, lands leased to the Washington Public Power Supply System, and lands owned by or leased to the state of Washington). 
DOE/RL-93-75

Rev. 2

1

This page intentionally left blank. 
DOE/RL-93-75

Rev. 2

\subsection{PURPOSE}

The Hanford Facility Contingency Plan, together with each TSD unitspecific contingency $p$ lan, meets the WAC 173-303 requirements for a contingency $p l a n$. Applicability of this plan to Hanford Facility activities is described in the Hanford Facility RCRA Permit, Dangerous Waste Portion, General Condition II.A. General Condition II.A applies to Part III TSD units, Part V TSD units, and to releases of hazardous substances which threaten human health or the environment. Additional information about the applicability of this document may also be found in the Hanford Facility RCRA Permit Handbook (DOE/RL-96-10).

This $\mathrm{plan}$ includes descriptions of responses to a nonradiological hazardous substance spill or release at Hanford Facility locations not covered by TSD unit-specific contingency plans or building emergency plans. The term hazardous substances is defined in WAC 173-303-040 as: "any liquid, solid, gas, or sludge, including any material, substance, product, commodity, or waste, regardless of quantity, that exhibits any of the physical, chemical or biological properties described in WAC 173-303-090 or 173-303-100." Whenever the term hazardous substances is used in this document, it will be used in the context of this definition.

This plan includes descriptions of responses for spills or releases of hazardous substances occurring at areas between TSD units that may, or may not, threaten human health or the environment. 
DOE/RL-93-75

Rev. 2

1

This page intentionally left blank. 


\subsection{EMERGENCY COORDINATORS}

The overall responsibility for implementation of this plan lies with personnel responsible for performing the duties of the Emergency Coordinator as discussed in WAC 173-303-360. Based upon applicability of this document through the Hanford Facility RCRA Permit to Hanford Facility activities as defined by Section 2.0, the Emergency Coordinator must be discussed in terms of Part III TSD units, Part V TSD units, and releases of hazardous substances.

Part III TSD units: The Emergency Coordinator at Part III TSD units (operating TSD units) will be personnel who are assigned to the TSD unit. Personnel providing outside support for emergency response will not assume the role of the Emergency Coordinator at Part III TSD units; however, they may be in charge of first response activities.

Part V TSD units: For Part V TSD units, the Emergency Coordinator approach will depend on whether a building or structure is present as part of the TSD unit. The Emergency Coordinator will be personnel who are assigned to the TSD unit when a building or structure is present. Personnel providing outside support for emergency response will not assume the role of the Emergency Coordinator at these Part V TSD units; however, they may be in charge of first response activities.

For Part $V$ TSD units that do not have a building or structure present as part of the TSD unit, the initial Emergency Coordinator will be Hanford Fire Department personnel who will also perform first response activities. The Hanford Fire Department will then delegate the Emergency Coordinator duties after the immediate threat of a release has been stabilized or eliminated. Remaining Emergency Coordinator duties will be delegated from the Hanford Fire Department to personnel who are assigned to the TSD unit after they are summoned to the event scene. TSD unit personnel will be summoned to the scene based upon the ljsting of Emergency Coordinators maintained at the single point-of-contact in accordance with Hanford Facility RCRA Permit (DW Portion) General Condition II.A.4.

Hazardous Substance release: The Emergency Coordinator for a hazardous substance release occurring at Part III TSD units and Part V TSD units undergoing closure will be the personnel discussed above for those locations. For other locations on the Hanford Facility considered areas between TSD units, the Emergency Coordinator title will be held by different personnel based upon two different scenarios.

Scenario 1: Release during transportation from one project ${ }^{2}$ to another. In this scenario, the Hanford Fire Department will serve as the initial Emergency Coordinator and will perform first response activities. The Hanford Fire

${ }^{1}$ The single point-of-contact is the Hanford Patrol Operations Center and/or the Pacific Northwest National Laboratory Security Center.

${ }^{2}$ This term is based upon information found in D0E $\backslash R L-91-28$, Chapter 1.0, Table 1-1 for Hanford Facility TSD units. 
DOE /RL-93-75

Rev. 2

Department will then delegate the Emergency Coordinator duties after the immediate threat of a release has been stabilized or eliminated. Remaining Emergency Coordinator duties will be delegated from the Hanford Fire Department to the organization that offered the hazardous substance for transportation. Delegation will occur after personnel from the offering organization are summoned to the event scene. Personnel will be summoned to the event scene based upon the listing of Emergency Coordinators maintained at the single point-of-contact in accordance with Hanford Facility RCRA Permit (DW Portion), General Condition II.A.4.

Scenario 2: Release during transportation to and from the same project or during product or waste storage. In this scenario, the organization responsible for the shipment or the hazardous substance in storage, will be notified and will serve as the Emergency Coordinator. Personnel providing outside support for emergency response will not assume the role of the Emergency Coordinator on these transportation events however they may be in charge of first response activities.

For any event, at any location, one Emergency Coordinator will be at the scene. When called to respond, the Hanford Fire Department's involvement will be limited to first response activities.

A 1 ist of all Emergency Coordinators and designated alternates is maintained in accordance with the Hanford Facility RCRA Permit (DW Portion) General Condition II.A.4. These individuals can be reached 24 hours per day. The Emergency Coordinator has the authority to commit all necessary resources (both equipment and personnel) to respond to any emergency.

Response by an Emergency Coordinator usually is obtained through the single point-of-contact by dialing the appropriate emergency telephone number: 911 or Pacific Northwest National Laboratory telephones at 375-2400. The Hanford Patrol Operations Center may also be reached by calling their business line, 373-3800. The single point-of-contact has been designated as the contact point to mobilize a response to any Hanford Facility emergency. The single point-of-contact is available at all times and can initiate notifications to the Emergency Coordinator or alternate to begin responses to emergencies, as well as to dispatch emergency responders (Hanford Fire Department, Hanford Patrol, or ambulance services). All emergency notifications to the Emergency Coordinator can be made directly from the affected facility or TSD unit or through the single point-of-contact.

The unit-specific DOE-RL technical contact responds to regulatory agency inquiries regarding this PIan. The unit-specific DOE-RL technical contact is accessed by contacting $373-3800$ or $375-2400$. 
DOE/RL-93-75

Rev. 2

\subsection{IMPLEMENTATION OF THE CONTINGENCY PLAN}

This Plan describes parallel decision flow paths for evaluating and classifying an incident. DOE orders and WAC 173-303-360 require incident classification. The definition of emergencies according to DOE orders differs from the definition contained in WAC 173-303. Because of this, a dual incident classification decision path is necessary to meet both DOE order and WAC 173-303 requirements. Incident classification according to DOE orders is described in this Plan for completeness only. DOE orders will not be used to evaluate whether an incident requires implementation of a contingency plan.

Implementation of a contingency plan will occur when an Emergency Coordinator has determined that a release, fire, or explosion has occurred at the facility which could threaten human health or the environment in accordance with sections 5.1.4 and 5.1.5 of this plan. A release is defined in WAC 173-303-040 within the definition of "discharge". An incident requiring evacuation of personnel or the summoning of emergency response units will not necessarily indicate that a contingency plan has been implemented.

Any incident that poses a potential threat to human health or the environment discovered by TSD unit personnel requires immediate notification of the Emergency Coordinator and the single point-of-contact who then notifies the Hanford Fire Department. Personnel may respond, in accordance with the procedures described in TSD unit-specific contingency plans, before the arrival of the Emergency Coordinator, as long as such response is within their level of training. The Hanford Fire Department is contacted through the single point-of-contact on all emergency incidents involving dangerous waste, mixed waste, or hazardous substances. 
DOE/RL-93-75

Rev. 2

This page intentionally left blank. 


\subsection{INCIDENT RESPONSE}

Incident response procedures have been established for each TSD unit. The initial response to any emergency will be to immediately protect the health and safety of persons in the immediate area. Identification of released material is essential to determine appropriate protective actions. Containment, treatment, and disposal assessment will be the secondary responses.

The following sections describe actions for personnel for several different types of incidents, including a generic response, that might occur on the Hanford Facility. Regardless of how an incident is classified, minimum on-site notification requirements exist to ensure the appropriate organizations are contacted and that the incident is correctly classified.

\subsection{INCIDENT GENERIC RESPONSES}

Unless indicated in subsequent response sections, the incident generic responses will apply to any event.

\subsubsection{Discoverer}

1. The discoverer makes immediate notifications to potentially affected personnel (including the Emergency Coordinator for a TSD unit incident, if onsite) of the incident.

2. IImmediately notifies the single point-of-contact by dialing the appropriate telephone number: 911, or Pacific Northwest National Laboratory telephones at 375-2400 and provides all known information, if the information can be obtained without jeopardizing personnel safety, including the following:

- Name(s) of chemical(s) involved and amount(s) spilled, on fire, or otherwise involved, or threatened by, the incident

- Name and callback telephone number of person reporting the incident

- Location of incident (identify as closely as possible and include information about multiple building numbers)

- Time incident began or. was discovered

- Where the materials involved are going or might go, such as into secondary containment, under doors, through air ducts, etc.

- Source and cause, if known, of spill or discharge

- Name(s) of anyone contaminated or injured in connection with the incident 
- Any corrective actions in progress

- Anyone else who the discoverer has contacted.

\subsubsection{Single Point-of-Contact}

1. Initiates notification to the Emergency Coordinator, or one of the alternates if the Emergency Coordinator cannot be reached immediately, to arrange immediate response to the incident

2. Requests immediate response from the Hanford Fire Department for fire, ambulance service, and/or hazardous substances/mixed waste incidents

3. Contacts the Hanford Patrol for traffic control and security measures, as needed, based on the report of the discoverer

4. Initiates notification to appropriate management of the spill or release incident

5. Supports the Emergency Coordinator in providing further notification and coordination of response activities if needed

6. Activates or requests activation of the appropriate alarm signals (as required) for the affected building or affected areas, when the Emergency Coordinator determines that protective actions are necessary

7. Notifies the emergency response organizations

8. Prompts activation of the affected area emergency control centers (ECC) if requested by the Emergency Coordinator or other authorized persons

9. Prompts activation of the DOE-RL Emergency Management Team (EMT), if necessary, to recommend protective actions for areas outside the Hanford Facility.

\subsubsection{Emergency Coordinator (or alternate)}

1. Sounds appropriate alarms to notify occupants

2. Notifies the single point-of-contact if additional support or an area evacuation is needed

3. Activates the building emergency response organization as necessary

4. Arranges for care of any injured persons

5. Requests the single point-of-contact to activate the affected ECC, if required. Activation of the ECC should be done whenever technical assistance is required in evaluating a spill, when the 


\subsubsection{Identification of Hazardous Substances and Dangerous Waste and Assessment of Hazards}

The Emergency Coordinator ensures that trained personnel identify the character, source, amount, and areal extent of the hazardous substance or dangerous waste involved in the incident to the extent possible. Identification of waste can be made by visual inspection of involved containers; by sampling; by reference to inventory records, shipping manifests, or waste tracking forms; or by consulting with TSD unit operations personnel. Samples of materials involved in an emergency might be taken by qualified personnel and analyzed as appropriate.

Concurrently, the hazards that the incident poses to human health and the environment must also be assessed. The assessment must take into consideration the direct, indirect, immediate, and long-term effects of the incident. In addition to the information sources identified above, the hazard assessment should include other sources such as Material Safety Data Sheet toxicjty and health information, and results from any personnel monitoring examinations conducted at medical facilities. These are the types of tools which will aid in ascertaining the extent in which human health and the environment were threatened.

Upon activation, the ECC is available to assist the Emergency Coordinator if needed. Possible assistance could include determining the extent of an emergency, identifying the hazards associated with the materials or waste involved in the incident, assisting in response to the incident, or coordinating the mobilization of special equipment or supplies to the incident site.

If assessment of al1 available information does not yield a positive assessment of the danger posed by the incident, a worst-case condition will be presumed and appropriate protective actions will be initiated. The Emergency Coordinator is responsible to initiate any protective actions.

\subsubsection{Incident Classification}

After the assessment has been completed in Section 5.1.4, the incident should be ready for classification. If not, the Emergency Coordinator shall take whatever means are necessary to obtain the information to complete the classification. The Emergency Coordinator must classify the incident according to the DOE order and contingency plan implementation criteria in this section. 
1. DOE Order Incident Classification

There are three categories of incidents on the Hanford Facility: offnormal event, unusual occurrence, and emergency as described in DOE Orders. Incidents are categorized based on degradation of TSD-unit safety systems and impact to other TSD units, employees, structures, public safety, and the environment. Incidents categorized as offnormal events and unusual occurrences are communicated as described in Section 9.0. Incidents categorized as an emergency are further classified into one of three emergency classes as required by DOE 0rders. Incidents categorized as emergencies will prompt automatic activation of the appropriate ECCs.

2. WAC 173-303 Incident Classification

Based upon the evaluation and hazard assessment in Section 5.1.4, the Emergency Coordinator may determine that the incident is classified as a release, fire, or explosion that threatens human health or the environment. When this occurs, the Emergency Coordinator must report his/her assessment to the ECC, if activated, or to the Patrol Operations Center by dialing 911 for dissemination to local authorities for evacuation of local areas, if applicable. In addition, the Emergency Coordinator or his/her designee, with assistance from environmental compliance/protection personnel, must immediately (within 2 hours) notify Ecology, and either the government official designated as the on-scene coordinator, or the National Response Center. The information included in the assessment report to these agencies is described in Section 9.0.

\subsubsection{Protective Actions}

1. Evacuation (Signal: Steady siren). Each TSD unit has a building emergency procedure that includes an evacuation plan identifying emergency signals and staging area location. In the event a Facility-wide evacuation is required, TSD unit personnel evacuate to their designated staging area, are accounted for, and receive directions on routes to take to safely evacuate the area. If the primary route is blocked by the emergency, personnel use alternate evacuation routes determined at the time of the event.

Evacuation routes for the Hanford Facility are shown on Figure 1. Specific routes will be determined at the time of the event based on event magnitude, location, and meteorology.

2. Take Cover (Signal: Wavering siren). In the event of a take cover alarm, personnel must go inside or remain inside, close all exterior doors, and turn off all intake ventilation. Personnel secure all waste and classified documents. 
DOE /RL-93-75

Rev. 2

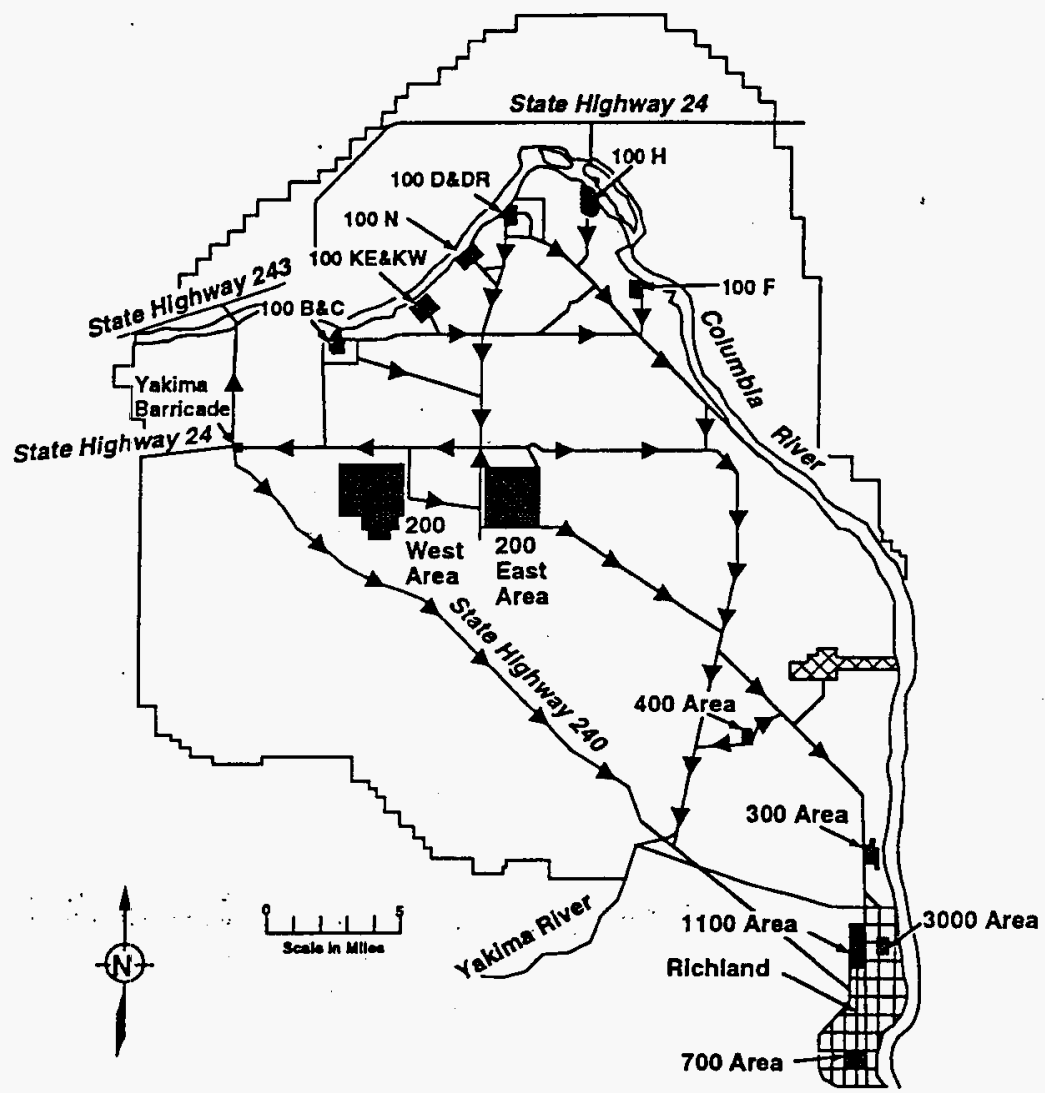

29200007.1

Figure 1. Hanford Facility Evacuation Routes. 


\subsection{RESPONSE TO MINOR SPILLS OR RELEASES AT TSD UNITS AND OTHER BUILDINGS}

(Signa 1: None) The TSD unit personnel generally perform immediate cleanup of minor spills or releases using sorbents and emergency equipment. Personnel detecting such spills or releases contact their supervisor or manager to notify of the detection of such release and to ensure notification of the Emergency Coordinator. In the event a supervisor or manager is not available, the discoverer may notify the single point-of-contact to ensure an Emergency Coordinator is contacted. Responses to spills or releases occurring within individual storage cells, structures, modules, etc., during routine handling and storage are contained in TSD unit-specific contingency plans and/or procedures. Response to minor spills does not require the implementation of the contingency plan in accordance with sections 5.1 .4 and 5.1 .5 .

A spill or release of hazardous substance or dangerous waste is considered 'minor' if all of the following are true:

- The spill does not threaten human health (e.g., an evacuation is not necessary)

- The spil1 does not threaten the environment

- non-emergency response personnel have received training to mitigate the spill and appropriate personal protective equipment is available

- The composition of the material or waste is known or can be quickly determined from label, manifest, material safety data sheets, or disposal request information.

If one or more of the foregoing conditions are not met, responses are performed as outlined in Section 5.3. Notification of the spill as outlined in Section 5.1 is not required for a minor spill or release.

\subsection{RESPONSE TO MAJOR SPILLS OR RELEASES AT TSD UNITS OR OTHER BUILDINGS}

(Signal: None) The following actions are taken in the event of a major spill or release. Response to major spills or releases may result in implementation of the contingency plan if the Emergency Coordinator makes this determination in accordance with Sections 5.1.4 and 5.1.5.

\subsubsection{Discoverer}

The discover performs the following:

1. If within the TSD unit, notify personnel (including the Emergency Coordinator) of discovery of spill or release by sounding the appropriate alarm, using the public address (PA) system, etc.

2. Initiate notifications to the single point-of-contact and provide all known information, in accordance with Section 5.1. 
DOE/RL-93-75

Rev. 2

3. Takes action to contain and/or to stop the spill if all of the following are true:

- The identity of the substance(s) involved is known

- Appropriate protective equipment and control/cleanup supplies are readily available

- Discoverer has received the appropriate training and can safely perform the action(s) without assistance, or assistance is readily available from other trained TSD unit personnel.

If any of the above conditions are not met, or there is any doubt, the discoverer evacuates the area and remains outside, upwind of the TSD unit, pending the arrival of the Emergency Coordinator. The discoverer remains available for consultation with the Emergency Coordinator, Hanford Fire Department, or other emergency response personnel.

\subsubsection{Single Point-of-Contact}

The single point-of-contact performs the following:

1. Notifies the Hanford Fire Department and relays information received from the event scene

2. Initiates notification to the Emergency Coordinator if not at the TSD unit

3. Remains available to support further notification and response activities if needed.

\subsubsection{Emergency Coordinator}

The Energency Coordinator performs or arranges for the following:

1. Proceeds directly to the TSD unit to coordinate further activity and to establish a command post at a safe location

2. Obtains all available information pertaining to the incident and determines if the incident requires implementation of the contingency plan

3. Determines need for assistance from agencies listed in Section 8.0 and arranges for their mobilization and response through the single point-of-contact

4. Initiates the appropriate alarm, if building or area evacuation is necessary,

5. Arranges for care of any injured persons 
6. Requests activation of the affected area ECC via the single-point of contact, if a threat to surrounding buildings or structures exists

7. Provides for event notification in accordance with Section 5.1

8. Maintains access control at the incident site by keeping unauthorized personnel and vehicles away from the area. Security personnel can be used to assist in site control if control of the boundary is difficult (e.g., repeated incursions). In determining controlled access areas, considers environmental factors such as wind velocity and direction

9. Arranges for proper remediation of the incident after evaluation.

10. Remains available for fire, patrol, and other authorities on the scene and provides all required information

11. Enlists the assistance of alternate Emergency Coordinator(s), if around-the-clock work is anticipated

12. Refers media inquiries to the Media Relations/Communications offices of the contractors or DOE-RL.

13. Ensures the use of proper protective equipment, remedial techniques (including ignition source control for flammable spills), and decontamination procedures by all involved personnel, if remediation is performed by TSD unit personnel. Areas of expertise are available in determining necessary equipment or procedures

14. Remains at the scene to oversee activities and to provide information, if remediation is performed by the Hanford Fire Department Hazardous Materials Response Team or other response teams

15. Ensures proper containerization, packaging, and labeling of recovered spill materials and overpacked containers

16. Ensures decontamination (or restocking) and restoration of emergency equipment used in the spill remediation before resuming TSD unit operations

17. Provides required reports after the incident in accordance with Section 9.0.

\subsubsection{Hanford Fire Department Response to Major or Unknown Spills}

The Hanford Fire Department response to unknown spills is as follows.

1. Initial Hanford Fire Department response includes one engine company, one hazardous materials unit, one ambulance unit, and one battalion commander. 
2. The Hanford Fire Department, as the Hazardous Materials Incident Command Agency, establishes command and control of the situation. The first arriving unit assumes incident command and determines location of the command post, and evacuates personnel from a redzone consisting of a minimum of 100 feet (30.5 meters) in all directions. The red zone could be adjusted as deemed necessary by the hazardous materials team leader.

3. The Incident Commander evacuates all personnel with in the red zone area.

4. The hazardous materials team leader establishes yellow zone and decontamination corridor.

5. The hazardous materials team leader assigns fully trained and qualified team members specific tasks i.e.,

Team Safety Officer Decontamination Team Leader

Entry Team

Backup Team

Resource Leader

Science Leader

6. The hazardous materials team safety leader controls and directs the medical evaluations for personnel working in the red and the yellow zones.

7. Team members performing entry, back up, and decontamination, suit up in level "A" protection.

8. Entry team members make entry to obtain samples of unknown hazardous substances, and observe for other pertinent information.

9. Entry team collects sample and exits area going through decontamination by decontamination team.

10. The sample is analyzed on scene by hazardous materials team personnel using available testing equipment. This testing is to determine hazard group classification i.e., poison, acid, flammable, oxidizer, etc.

11. Once hazard classification has been identified, hazardous materials entry team makes re-entry to stabilize and control the hazardous substance to the point that the emergency no longer exists.

12. The entry team exits the area going through decontamination by decontamination team.

13. The hazardous materials team leader informs the Emergency Coordinator that the spill site is ready for cleanup by cleanup personnel.

14. The hazardous materials response command is dissolved; all units return to stations. 
15. A critique of the hazardous materials incident is held with team members as soon as possible after Hanford Fire Department units have returned to stations.

\subsection{RESPONSE TO FIRE}

(Signal: Gong) In the event of a fire, the discoverer activates a fire alarm and calls the single point-of-contact in accordance with Section 5.1.1. Automatic initiation of a fire alarm (through the smoke detectors and sprinkler systems) also is possible. The TSD unit personnel are trained in the use of portable fire extinguishers for incipient fires. Personnel use their best judgment whether to fight a fire or to evacuate. Under no circumstances do personnel remain to fight a fire if unusual hazards exist.

The following actions are taken in the event of a fire or explosion.

1. On actuation of the fire alarm, personnel shut down equipment, secure waste (especially mixed waste), and lock up classified documents (or carry the documents with them), ONLY if time permits. The alarm automatically signals the Hanford Fire Department and the Patrol Operations Center.

2. Personnel leave the area/building by the nearest safe exit and proceed to the designated staging area for accounting. ${ }^{3}$

3. The single point-of-contact is notified immediately, who in turn initiates notifications to the Emergency Coordinator (or alternate) if necessary.

4. The Emergency Coordinator proceeds directly to the scene (if not already there).

5. The Emergency Coordinator obtains all necessary information pertaining to the incident.

6. Depending on the severity of the event, the Emergency Coordinator or his/her designee may be required to provide notifications to offsite agencies in accordance with section 5.1 .5 and section 9.0 informing them as to the extent of the emergency (including estimates of dangerous waste and/or mixed waste quantities released to the environment) and any actions necessary to protect nearby buildings and/or structures.

7. Depending on severity, the Emergency Coordinator requests activation of the affected area ECC to establish organizations to provide assistance from the DOE-RL, other Hanford Facility contractors, and outside agencies.

\footnotetext{
${ }^{3}$ During a fire alarm condition, all building occupants are required to evacuate unless otherwise stated in their specific building emergency plan.
} 
$\mathrm{DOE} / \mathrm{RL}-93-75$

Rev. 2

8. The Hanford Patrol establishes roadblocks within the area to route traffic away from the emergency scene.

9. Hanford Fire Department medical personnel remove injured personnel to a safe location, apply first aid, and prepare the injured for transport to medical aid stations or to local hospitals in accordance with established memoranda of understanding (MOUS) summarized in Section 8.0. Medical personnel are on standby 24 hours per day.

10. Hanford Fire Department fire fighters extinguish the fire.

11. Al1 emergency equipment is cleaned and fit for its intended use following completion of cleanup procedures.

\subsection{UNUSUAL, IRRITATING, OR STRONG ODORS}

(Signal: None) If an unusual, irritating, or strong odor is detected, and the discoverer has reason to believe that the odor might be the result of an uncontrolled release of a toxic or dangerous material, the discoverer performs the following:

- Activates the building evacuation alarm or fire alarm system to evacuate the building

- Notifies the single point-of-contact, the building manager, and cognizant line management.

If the discoverer knows of the source and scope of the release, this information is reported quickly to the Emergency Coordinator. Measures are taken to contain the release and ventilate the area, if safe and advisable to do so.

If an unusual odor is detected within the building or structure, and the source of the odor is unknown, the Emergency Coordinator considers additional protective actions.

\subsection{RESPONSE TO CONTAINER SPILLS OR LEAKS}

In addition to the foregoing Plan provisions, the following specific actions could be taken for leaks or spills from containers at ISD units. These actions may be taken only by appropriately trained personnel.

- Container leaks are stopped as soon as possible using appropriate procedures. Appropriate personnel protective equipment is used.

- If it is inadvisable to approach the container, absorbent materials are used, and access is restricted pending notification of the Emergency Coordinator. 
DOE $/$ RL-93-75

Rev. 2

- Contents of leaking containers could be transferred to appropriate nonleaking containers. Transfer procedures for fire safety are followed for ignitable or reactive waste (e.g., use of nonsparking tools, bonding and grounding of containers, isolation of ignition sources, and use of explosion-proof electrical equipment).

- Overpacked containers are marked and labeled in the same manner as the contents. All containers of spill debris, recovered product, etc., are managed in the same manner as waste containers received from outside the TSD unit. Overpacks in use at the TSD unit are marked with information pertaining to their contents and noted as to whether the container inside the overpack is leaking or is in good condition.

\subsection{RESPONSE TO TRANSPORTATION INCIDENTS}

This section describes the actions taken in the event of an unplanned sudden or nonsudden release of hazardous substances, dangerous waste, and/or mixed waste to air, soil, surface water, or groundwater during transportation activities on the Hanford Facility. This includes spills or releases of hazardous substances occurring at areas between TSD units that may, or may not, threaten human health or the environment. For spills or releases of hazardous substances occurring at TSD units or other buildings, consult Sections 5.2, 5.3, and 5.6. See Section 2.0 for the definition of hazardous substances.

The following steps are performed by those individuals discovering and responding to a hazardous substance transportation incident at the Hanford Facility. In addition, Emergency Coordinator steps are provided which occur after initial responder actions have been completed. Discoverer notifications for transportation incidents will not be accomplished in accordance with Section 5.1.1. but in accordance with Section 5.7.1.

\subsubsection{Discoverer}

The discoverer of a hazardous substance spill or release resulting from transportation activities may be the driver of a truck, the engineer of a railroad locomotive, support personnel associated with the transportation activity, or someone who is not involved in the transportation activity but witnesses the incident. The discoverer:

- Initiates notifications to the single point-of-contact by any means available (telephone, radio, passing motorist, etc.) to request assistance unless personnel associated with the transportation activity have received training to directly contact an Emergency Coordinator.

- Remains in a safe location. 
DOE/RL-93-75

Rev. 2

- If appropriate training has been completed, the discoverer can assist injured personnel and attempt to isolate the area to prevent inadvertent personne 1 access.

\subsubsection{Initial Responder Actions}

The Hanford Fire Department will be the initial responder for most transportation incidents on the Hanford Facility. The Hanford Fire Department will be summoned to the incident scene primarily via the single point-ofcontact. In 1 imited cases, TSD unit personnel and/or Hanford Patrol will also provide initial responder actions based upon the training they have received and the severity of the incident. Prevention of further spills or releases is the primary goal to mitigating a transportation incident second only to protection of personnel. The initial responder wi11:

- Isolate event from personnel:

- Cordon off access

- P1ace apparatus to block roadways

- Use Hanford Patrol roadblocks

- Use TSD unit/vehicle PA systems

- Sound appropriate alarms.

- Determine type of hazardous substances involved by consulting with the driver or locomotive engineer, shipping papers, container placards and labels, and any other resources available to the initial responder.

- Coordinate with emergency response organizations to estab]ish a command post, upwind and uphill of the incident.

- Ensure that a11 personnel who enter the area are equipped with proper protective clothing and respiratory protection

- Complete other actions necessary to effect control of the scene, including but not limited to the following:

NOTE: The following steps normally are conducted and/or directed by a Hanford Fire Department Hazardous Materials Response Team leader.

- Secure the scene

- Use absorbents

- Use covering (blankets, polyethylene, etc.)

- Overpack

- Plug/patch

- Transfer to new container

- Venting/vapor suppression.

- Summon the Emergency Coordinator to the incident scene if not already there by communicating with the single point-of-contact. The single point-of-contact maintains the list of Emergency Coordinators in order to summon personnel from the organization 


\subsubsection{Emergency Coordinator}

The Hanford Fire Department will serve as the initial Emergency Coordinator and will perform first response activities for most transportation incidents. Emergency Coordinator duties met by the Hanford Fire Department will be those pertaining to stabilizing or eliminating the immediate threat of further release of the hazardous substance described above. The Hanford Fire Department will not be the initial Emergency Coordinator when another Emergency Coordinator is at the transportation incident. The Hanford Fire Department may still perform, and be in charge of initial responder actions.

When the Hanford Fire Department is the initial Emergency Coordinator, they will delegate the Emergency Coordinator duties after the immediate threat of a release has been stabilized or eliminated. Remaining Emergency Coordinator actions are to:

- Ensure that the cause of the incident and its possible effects are investigated and evaluated as soon as possible.

- Assess possible hazards to human health and the environment (considering direct, indirect, immediate, and long-term effects) that might result from the release, fire, or explosion in accordance with Section 5.1.4.

- Determine whether the incident is a release, fire, or explosion that could threaten human health or the environment in accordance with Section 5.1.5.

- Terminate the event and recover from the incident in accordance with section 6.0 .

- Complete required reports in accordance with section 9.0.

\subsection{DAMAGED, UNACCEPTABLE SHIPMENTS}

(Signal: None) When a damaged shipment of hazardous substance, or dangerous waste/mixed waste arrives at a TSD unit and the shipment is unacceptable for receipt, the damaged shipment should not be moved. The TSD unit personnel instead perform the following steps. 
D0E/RL-93-75

Rev. 2

- If the release from damaged package is a 'minor' spill under the criteria of Section 5.2, the following actions are performed.

- Notify the supervisor or manager to advise of the situation. The supervisor or manager contacts the Emergency Coordinator in order to respond and assist in the evaluation of, and response to, the incident.

- Notify the shipper or generating unit of the damaged shipment and request that they provide any chemical information necessary to assist in responding to the 'minor' spill.

- Proceed with remedial action, including overpacking, damaged containers, cleanup of spilled materiai, or other necessary actions to contain the spill.

- Implement the TSD unit contingency plan if applicable in accordance with section 5.1.5, if the release does not meet the criteria of a 'minor' spill as noted previously, or the extent of the spill cannot be determined.

\subsection{PREVENTION OF RECURRENCE OR SPREAD OF FIRES, EXPLOSIONS, OR RELEASES}

The Emergency Coordinator, in coordination with emergency response organizations, takes the steps necessary to ensure that a secondary release, fire, or explosion does not occur. The following actions are taken:

- Isolate the area of the initial incident by shutting off power, closing off ventilation systems, etc., to minimize the spread of a release and/or the potential for a fire or explosion

- Inspect containment for leaks, cracks, or other damage

- Inspect for toxic vapor generation

- Remove released material and waste remaining inside of containment structures as soon as possible

- Contain and isolate residual waste material using dikes and adsorbents

- Cover or otherwise stabilize areas where residual released materials remain to prevent migration or spread from wind or precipitation run-off

- Install new structures, systems, or equipment to enable better management of hazardous substances or dangerous waste

- Reactivate adjacent operations in affected areas only after cleanup of residual waste materials is achieved. 
DOE/RL-93-75

Rev. 2

This page intentionally left blank 
D0E/RL-93-75

Rev. 2

\subsection{TERMINATION OF EVENT}

It is a function of the Emergency Coordinator to declare the termination of an event. However, in an event where additional emergency centers are activated only the highest activated level of the emergency organization, in conjunction with the Emergency Coordinator, will declare that an event has ended. If the RL-EMT is activated, only the RL-EMT Emergency Manager officially terminates the event. In all cases, however, the Emergency Coordinator must be consulted before reentry is initiated.

\subsection{INCIDENT RECOVERY AND RESTART OF OPERATIONS}

A recovery $\mathrm{plan}$ is developed when necessary. A recovery $\mathrm{plan}$ is needed following an event when further risk could be introduced to personnel, a TSD unit, or the environment through recovery action and/or to maximize the preservation of evidence. If a recovery plan is required, it is reviewed by appropriate personnel and approved before restart. Restart of operations is performed in accordance with the approved plan.

If the contingency plan was implemented, notification must be made to Ecology before operations can resume. Section 9.0 discusses different reports to outside agencies. This notification is in addition to the required reports in Section 9.0. This notification must include that there are no incompatibility issues with the waste and released materials from the incident, and that all the equipment has been cleaned, is fit for its intended use and placed back into service. The notification may be made via telephone conference. Any additional information that Ecology requests regarding these restart conditions may be included in the required 15-day report identified in Section 9.0.

For emergencies not involving activation of the ECC, the Emergency Coordinator ensures that conditions are restored to normal before operations are resumed. If the ECC was activated and the emergency phase is complete, a special recovery organization could be appointed at the discretion of the Emergency coordinator to restore conditions to normal. The makeup of this organization depends on the extent of the damage and its effects. The recovery organization will be appointed by the appropriate contractors' emergency director.

\subsection{INCOMPATIBLE WASTE}

After an event, the Emergency Coordinator or the recovery organization ensures that no waste that might be incompatible with the released material is treated, stored, and/or disposed of until cleanup is completed. Cleanup actions are taken by TSD unit operations personnel or other assigned personnel. Actions to be taken might include, but are not limited to, any of the following: 
DOE/RL-93-75

Rev. 2

- Neutralization of corrosive spills

- Chemical treatment of reactive materials to reduce hazards

- Overpacking or transfer of contents from leaking containers

- Use of sorbents to contain and/or absorb leaking liquids for containerization and disposal

- Decontamination of solid surfaces impacted by released material, e.g., intact containers, equipment, floors, containment systems, etc.

- Disposal of contaminated porous materials that cannot be decontaminated and any contaminated soil

- Containerization and sampling of recovered materials for classification and determination of proper disposal technique

- Follow up sampling of decontaminated surfaces to determine adequacy of cleanup techniques as appropriate.

Waste from cleanup activities is designated and managed as newly generated waste. A field check for compatibility before storage is performed as necessary. Incompatible wastes are not placed in the same container. Containers of waste are placed in storage areas appropriate for their compatibility class.

If it is determined that incompatibility of waste was a factor in the incident, the Emergency Coordinator or the recovery organization ensures that the cause is corrected. Examples would be modification of an incompatibility chart or increased scrutiny of waste from a generating unit when incorrectly designated waste caused or contributed to an incident.

\subsection{POST-EMERGENCY EQUIPMENT MAINTENANCE AND DECONTAMINATION}

A11 equipment used during an incident is decontaminated (if practicable) or disposed of as spill debris. Decontaminated equipment is checked for proper operation before storage for subsequent use. Consumables and disposed materials are restocked. Fire extinguishers are recharged or replaced.

The Energency Coordinator ensures that all equipment is cleaned and fit for its intended use before operations are resumed. Depleted stocks of neutralizing and absorbing materials are replenished, self-contained breathing apparatus are cleaned and refilled, protective clothing are cleaned or disposed of and restocked, etc.

Equipment and personnel decontamination stations are established considering the following information and techniques. 
Items to consider when establishing a decontamination station are as follows:

- Water supplies

- Containment/catch basins and/or systems

- Staff necessary to accomplish proper decontamination

- Protective clothing

- Decontamination supplies (buckets, brushes, soap, chemicals as needed)

- Risk to personne1

- Weather conditions; i.e., severe heat, cold (current and forecasted)

- Toxicity of material

- Porosity of equipment to be decontaminated

- Disposal requirements of decontamination rinse

- Use of controlled zones to maintain contamination control. 


\section{DOE/RL-93-75}

Rev. 2

This page intentionally left blank. 
$\mathrm{DOE} / \mathrm{RL}-93-75$

Rev. 2

\subsection{EMERGENCY EQUIPMENT AND RESOURCES}

\subsection{HANFORD FACILITY EMERGENCY CENTERS}

The emergency centers are those locations staffed to provide assistance to building emergency organizations in an emergency situation. The emergency centers are established to support and to provide overall direction of emergency events occurring at locations within their geographic area of responsibility, within the Hanford Facility. This includes acquisition of and assignment of resources to respond to emergency events. Responsibilities also include personnel protection (employee and public), TSD unit safety, and environmental protection. The establishment of emergency centers ęnsures that notification and communication of emergency conditions are communicated properly.

There are several emergency centers located throughout the Hanford Facility and Hanford Site (Table 1).

\subsection{COMMUNICATIONS EQUIPMENT}

The Hanford Facility has alarm systems that are monitored by the Hanford Fire Department and the Patrol Operations Center. The alarm signals that exist at the Hanford Facility are identified in Table 2. The TSD unit operations personnel also may use telephones, building PA systems, portable radios, and cellular telephones to summon assistance.

\subsection{FIRE CONTROL EQUIPMENT}

Many Hanford Facility buildings are equipped with automatic firesuppression (sprinkler) systems. Portable fire extinguishers are located in working areas in compliance with National Fire Protection Association safety codes. Each Class $A B C$ extinguisher is capable of suppressing fires involving ordinary combustible materials, flammable liquids, oils, paints, flammable gases, and electrical equipment. All extinguishers comply with the National Fire Code standards for portable extinguishers and are inspected monthly. The inspections are recorded on tags attached to each extinguisher.

\subsection{PERSONAL PROTECTIVE EQUIPMENT}

The TSD units have safety showers and eyewash stations, located as necessary, for personnel protection. Drainage from these stations is contained. In addition to these stations, portable eyewash equipment is maintained at protective storage areas as necessary. These eyewash/shower stations are inspected regularly.

Protective clothing and respiratory protective equipment are maintained for use during both routine and emergency operations. This equipment is identified in the unit-specific contingency plans. 
DOE/RL-93-75

Rev. 2

Table 1. Emergency Centers.

300 Area Emerqency Control Center

\begin{tabular}{|l} 
Emergency Centers \\
\hline Northern Area Emergency Control Center \\
Location: $2750-E, 200$ East Area
\end{tabular}

Geographic area of responsibility:

A1] 100 and 200 Areas plus the 600 Area north of the WYE Barricade bounded by the Columbia River and Highway 240.

Geographic area of responsibility:

RCHS, RCHC, RCHN, 1100 and 3000 Areas plus the 600 Area south of the WYE Barricade bounded by the Columbia River and Highway 240.

400 Area Emergency Control Center

Geographic area of responsibility: Location: Fast Flux Test Facility, 400 Area. 400 Area

Battelle, Pacific Northwest

National Laboratories operated

facilities located in the RCHN

DOE-RL Emergency Operations Center area. centers, coordinating the Facilitywide response to emergencies, serving as the focal point for other Hanford Site contractors and DOE-RL during emergencies and for providing overall direction for all Hanford Facility emergency situations involving the DOE-RL and/or contractor personnel, ensuring direct interface with all offsite agencies for mitigation and protection of offsite populations, facilities, and the environment.

RCHS = Richland South.

RCHC = Richland Central.

RCHN = Richland North. 
DOE/RL-93-75

Rev. 2

Table 2. Hanford Facility Alarm Systems.

3

4

5

6

7

8

9

10

\begin{tabular}{|l|l|l|}
\hline \multicolumn{1}{|c|}{ Signal } & \multicolumn{1}{|c|}{ Meaning } & \multicolumn{1}{c|}{ Response } \\
\hline $\begin{array}{l}\text { Crash Alarm Telephones } \\
\text { (red telephone) }\end{array}$ & $\begin{array}{l}\text { Emergency } \\
\text { message }\end{array}$ & $\begin{array}{l}\text { Lift receiver, do not speak, listen to } \\
\text { caller and relay message(s) to } \\
\text { building occupants and Emergency } \\
\text { Coordinator or alternate. }\end{array}$ \\
\hline Gong (2 gongs/second) & Fire & $\begin{array}{l}\text { Evacuate building. Move upwind. Keep } \\
\text { clear of emergency vehicles. }\end{array}$ \\
\hline Siren (steady blast) & $\begin{array}{l}\text { Area } \\
\text { evacuation }\end{array}$ & $\begin{array}{l}\text { Proceed promptly to accountability } \\
\text { area. Follow instructions. }\end{array}$ \\
\hline Wavering Siren & Take cover & $\begin{array}{l}\text { Close all exterior doors, turn off a11 } \\
\text { intake ventilation and notify manager } \\
\text { of whereabouts. Request call back for } \\
\text { status and monitor portable radios. }\end{array}$ \\
\hline Howler (AA-00-GAH) & Criticality & $\begin{array}{l}\text { Immediately run to the nearest exit } \\
\text { and move and remain at least 100 feet } \\
\text { (30.5 meters) from the building. }\end{array}$ \\
\hline
\end{tabular}

11 
DOE/RL-93-75

Rev. 2

\subsection{SPILL CONTROL AND CONTAINMENT SUPPLIES}

Supplies of absorbent pillows are located in operating areas as necessary. These pillows absorb organic or inorganic materials and have a rated absorption capacity of approximately 0.26 gallon (1 liter) of waste each. Absorbents might be used for barriers to contain iqquid spills as well as for absorbent purposes. Diatomaceous earth for absorption of 1iquid waste spills is available. Neutralizing absorbent is available for response to acid or caustic spills. A supply of empty containers and salvage containers (overpacks) also are maintained as well as brooms, shovels, and miscellaneous spill response supplies.

\subsection{HANFORD SITE EMERGENCY ORGANIZATIONS}

The Hanford Facility has fire and patrol personnel trained and equipped to respond in emergency situations. The Hanford Fire Department is the Hazardous Materials Incident Command Agency for the Hanford Site and has a Hazardous Materials Response Team that is trained to stabilize and control hazardous substances emergencies. A description of equipment for hazardous substances responses available through the Hazardous Materials Response Team is given in Table 3 . Locations of the four fire stations on the Hanford Facility are shown on Figure 2.

The Hanford Patrol provides support to the Hanford Fire Department during an incident, including such activities as activation of area crash alarm telephone systems or area sirens (for evacuation or take cover), access control, traffic control, and assistance in emergency notifications. 
DOE/RL-93-75

Rev. 2

Table 3. Fire Department Equipment List. (sheet 1 of 3 )

\begin{tabular}{|c|c|c|}
\hline Equipment & Description & $\begin{array}{l}\text { *Normally } \\
\text { Located }\end{array}$ \\
\hline $\begin{array}{l}\text { Engines } \\
4 \text { Ladders } \\
4 \text { Pumpers }\end{array}$ & $\begin{array}{l}\text { Examples of equipment contained on } \\
\text { engines: } \\
\text { - 1,500-2,000 gal/min }(5,678.1- \\
7,570.8 \mathrm{~L} / \mathrm{min}) \text { pump } \\
\text { - } 300-500 \mathrm{gal}(1,135.6-1,892.7 \mathrm{~L}) \\
\text { portable tank } \\
\text { - Telescoping nozzle } \\
\text { - Jaws of Life. }\end{array}$ & $\begin{array}{l}\text { l at each } \\
\text { station }\end{array}$ \\
\hline $\begin{array}{l}\text { Tankers } \\
6 \text { Each }\end{array}$ & $\begin{array}{l}\text { Examples of equipment contained on } \\
\text { tankers and pumpers: } \\
\text { - } 500 \mathrm{gal} / \mathrm{min}(1,892.7 \mathrm{~L} / \mathrm{min}) \text { pump } \\
\text { - } 1,500 \mathrm{gal}(5,678.1 \mathrm{~L}) \mathrm{tank} \\
6 \times 6 \text { with } 2,000 \mathrm{gal}(7,570.8 \mathrm{~L}) \\
\text { porti-tank } \\
\text { Hose, nozzles, fittings, and } \\
\text { tools. }\end{array}$ & $\begin{array}{l}1 \text { at Station } 1 \\
2 \text { at Station } 2 \\
1 \text { at Station } 4 \\
2 \text { at Station } 3\end{array}$ \\
\hline $\begin{array}{l}\text { Water Tenders } \\
1 \text { Each }\end{array}$ & $\begin{array}{l}\text { Examples of equipment contained on } \\
\text { water tenders: } \\
\text { - } 450 \mathrm{gal} / \mathrm{min}(1,703.4 \mathrm{~L} / \mathrm{min}) \text { pump } \\
\text { - } 4,500 \mathrm{gal}(17,034.3 \mathrm{~L}) \text { tank } \\
\text { Hose, nozzles, fittings, and } \\
\text { tools. }\end{array}$ & Station 1 \\
\hline $\begin{array}{l}\text { Grass Fire Units } \\
4 \text { Each }\end{array}$ & $\begin{array}{l}\text { Examples of equipment contained on } \\
\text { grass fire units: } \\
\text { - } 100 \mathrm{gal} / \mathrm{min}(378.5 \mathrm{~L} / \mathrm{min}) \text { pump } \\
\text { - } 250 \mathrm{gal}(946.3 \mathrm{~L}) \text { tank } \\
\text { - Hoseel drive } \\
\text { tools. }\end{array}$ & $\begin{array}{l}\text { l at each } \\
\text { station }\end{array}$ \\
\hline $\begin{array}{l}\text { Ambulances } \\
5 \text { Each }\end{array}$ & $\begin{array}{l}\text { Examples of equipment contained on } \\
\text { ambulances: } \\
\text { - Life support systems } \\
\text { - Medical supplies and emergency } \\
\text { response supplies. }\end{array}$ & $\begin{array}{l}1 \text { at Station } 1 \\
2 \text { at Station } 2 \\
1 \text { at Station } 3 \\
1 \text { at Station } 4\end{array}$ \\
\hline $\begin{array}{l}\text { Command Vehicles } \\
3 \text { Each }\end{array}$ & $\begin{array}{l}\text { Contains communications equipment and } \\
\text { protective equipment for commander. }\end{array}$ & Station 2 \\
\hline
\end{tabular}


DOE/RL-93-75

Rev. 2

Table 3. Fire Department Equipment List. (sheet 2 of 3)

\begin{tabular}{|c|c|c|}
\hline Equipment & Description & $\begin{array}{l}\text { *Normally } \\
\text { Located }\end{array}$ \\
\hline $\begin{array}{l}\text { Attack Vehicles } \\
1 \text { Each }\end{array}$ & $\begin{array}{l}\text { Examples of equipment contained on } \\
\text { attack vehicles: } \\
\text { - } 450 \mathrm{lb}(204.1 \mathrm{~kg}) \text { of purple-k } \\
\text { - } 300 \mathrm{gal}(1,1335.6 \mathrm{~L}) \text { aqueous film- } \\
\text { forming foam concentrate } \\
\text { - } 300 \mathrm{gal}(1,135.6 \mathrm{~L}) \text { of aqueous } \\
\text { film-forming foam pre-mix solution } \\
\text { - Hose, nozzles, fittings, and } \\
\text { tools. }\end{array}$ & Station 2 \\
\hline $\begin{array}{l}\text { Hazardous } \\
\text { Materials Vehicle } \\
2 \text { Each }\end{array}$ & $\begin{array}{l}\text { Examples of equipment contained on } \\
\text { hazardous materials vehicle: } \\
\text { - Protective clothing for Hazardous } \\
\text { Materials Response Team } \\
\text { - Breathing apparatus for Hazardous } \\
\text { Materials Response Team } \\
\text { - Diking, plugging, and damming } \\
\text { equipment } \\
\text { - Detection instruments for } \\
\text { Hazardous Materials Response Team } \\
\text { - Tools for plugging and repairing } \\
\text { leaking containers } \\
\text { - Overpack containers for leaking } \\
\text { containers } \\
\text { - Command module with material } \\
\text { safety data sheets, software, and } \\
\text { portable meteorological station } \\
\text { - Tools and communications devices } \\
\text { necessary to provide } \\
\text { communications during emergency } \\
\text { response activities. }\end{array}$ & $\begin{array}{l}1 \text { at Station } 2 \\
1 \text { at Station } 3\end{array}$ \\
\hline $\begin{array}{l}\text { Metal Fire } \\
\text { Response Vehicle } \\
\text { l Each }\end{array}$ & $\begin{array}{l}\text { Examples of equipment contained on } \\
\text { metal fire response vehicle: } \\
\text { - Equipment for response to special } \\
\text { metals fire } \\
\text { - } 5001 \mathrm{~b}(226.8 \mathrm{~kg}) \text { of extinguishing } \\
\text { powder } \\
\text { - } 1,0001 \mathrm{~b}(453.6 \mathrm{~kg}) \text { of carbon } \\
\text { microspheroids. }\end{array}$ & Station 4 \\
\hline
\end{tabular}


DOE/RL-93-75

Rev. 2

Table 3. Fire Department Equipment List. (sheet 3 of 3)

\begin{tabular}{|l|l|l|l|}
\hline \multicolumn{1}{|c|}{2} & \multicolumn{1}{|c|}{ Equipment } & \multicolumn{1}{c|}{ Description } & \multicolumn{1}{|c|}{$\begin{array}{c}\text { Normally } \\
\text { Located }\end{array}$} \\
\cline { 2 - 4 } 5 & $\begin{array}{l}\text { Mobile Air } \\
\text { Vehicle }\end{array}$ & $\begin{array}{l}\text { Examples of equipment contained on } \\
\text { mobile air vehicle: } \\
\text { - Mobile air compressor, recharges } \\
\text { self-contained breathing apparatus } \\
\text { cylinders } \\
\text { Tools and fittings for operation } \\
\text { of vehicle and spare cylinders. }\end{array}$ & Station 4 \\
\hline
\end{tabular}

7 *The Hanford Fire Department Chief has the authority to direct the 8 placement of Fire Department equipment as needed to control emergency events. The Hanford Fire Department Chief also has the authority to take pro-active action and assign different vehicle locations based on such conditions as fuel moisture content, area fire history, work in progress, or other conditions that could arise.

$$
\begin{aligned}
\mathrm{gal} & =\text { gallon(s) } \\
\text { gal } / \min & =\text { gallon(s) per minute } \\
\mathrm{kg} & =\mathrm{kilogram}(\mathrm{s}) \\
\mathrm{L} & =1 \mathrm{iter}(\mathrm{s}) \\
\mathrm{L} / \mathrm{min} & =\operatorname{liter}(\mathrm{s}) \text { per minute } \\
\mathrm{lb} & =\operatorname{pound}(\mathrm{s})
\end{aligned}
$$


DOE/RL-93-75

Rev. 2

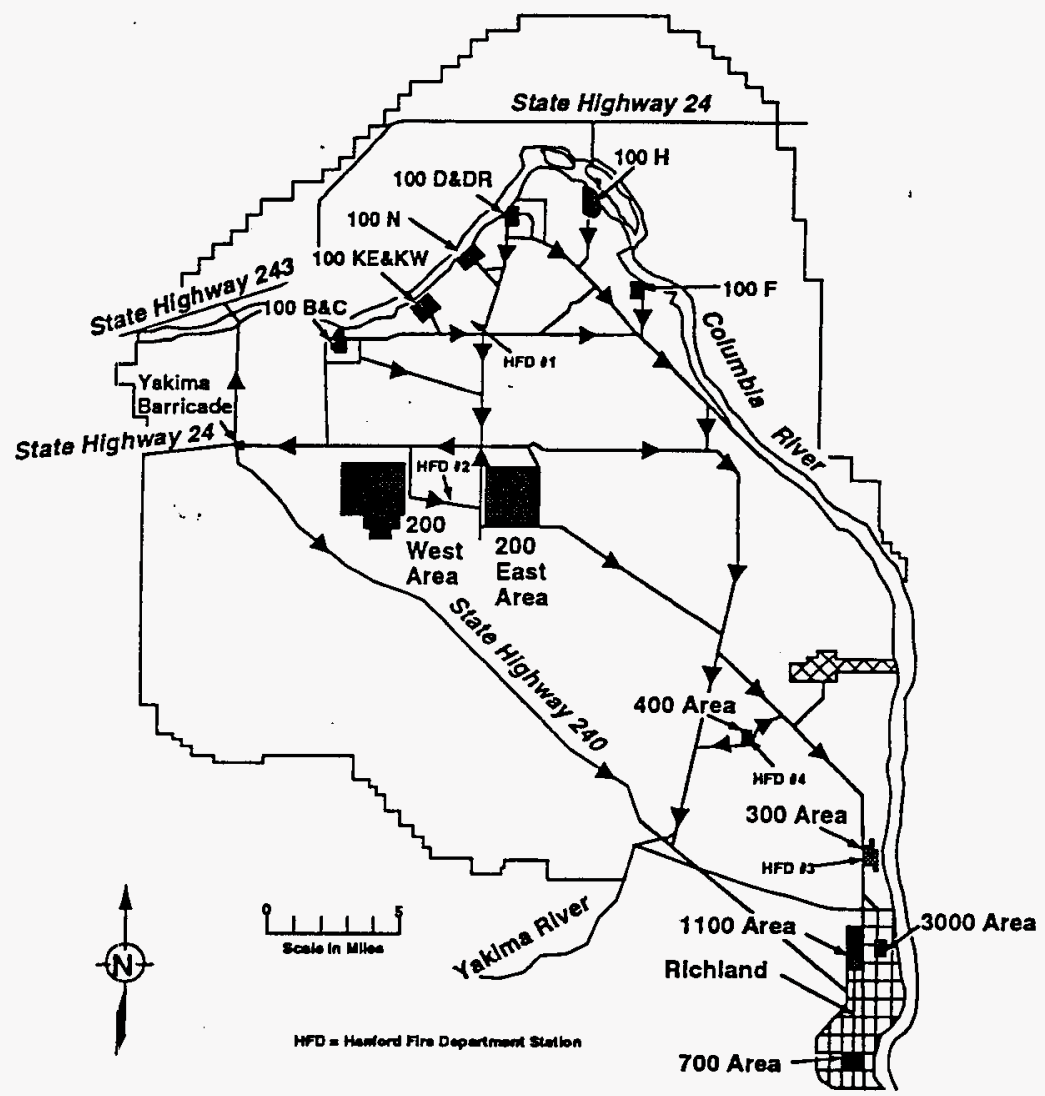

24700007.

Figure 2. Locations of the Fire Stations on the Hanford Facility. 
DOE $/ R L-93-75$

Rev. 2

\subsection{COORDINATION AGREEMENTS}

This section describes a number of coordination agreements (MOUs) established by and through the DOE-RL to ensure proper response resource availability for incidents involving the Hanford Facility.

An agreement among the major Hanford Site contractors (an operations, engineering and construction contractor, an environmental restoration contractor, a research and development contractor, and a medical and health services contractor) defines the interfaces and notifications required during an emergency. The DOE-RL has the overall responsibility for emergency preparedness. Per the agreements, the operations and engineering çontractor has responsibility for site-wide emergency preparedness while each contractor retains responsibility for emergency preparedness at individual units. Agreements have been established with a number of offsite authorities to reduce the impact to human health and/or the environment in the event that an incident has offsite public health implications, or if an onsite emergency warrants offsite assistance. These agreements are activated through the emergency notification of the DOE-RL (Section 4.1).

\subsection{LOCAL, STATE, AND FEDERAL AUTHORITIES}

Various agreements have been established among the DOE-RL and Benton, Franklin, and Grant Counties and the states of Washington and Oregon. These agreements describe the cooperative arrangements among these agencies for any onsite emergency that warrants offsite assistance. These agreements describe the planning for, communication of, and response to emergencies at the Hanford Facility that might have offsite consequences.

\subsection{HANFORD FIRE DEPARTMENT MUTUAL AID}

The Hanford Fire Department provides fire department services for the Hanford Site and Hanford Facility. Mutual aid agreements have been established with Richland, Kennewick, and Pasco fire departments; with Benton County Fire Districts 1 through 6, Frankl in County Fire District 3, and Walla Walla Fire District 5.

\subsection{MEDICAL AND FIRST AID}

Professional medical help is provided onsite by the DOE-RL through the Hanford Environmental Health Foundation. Doctors and nurses are available for emergency assistance at all times. These medical personnel are trained in procedures to assist personnel contaminated with hazardous and/or radioactive material. Emergency call lists are maintained to provide professional medical consultation at all times.

Referral to offsite hospital facilities is made by the Hanford Environmental Health Foundation physician providing emergency assistance by telephone or in person. The primary hospital used in emergencies is Kadlec 
Hospital, Richland. Kennewick General Hospital, Kennewick, and Our Lady of Lourdes Hospital, Pasco, are used as backup facilities. Agreements have been established among these hospitals and the DOE-RL.

\subsection{AMBULANCE SERVICE}

Ambulance service is provided by the Hanford Fire Department, which uses paramedics and emergency medical technicians as attendants. This service is available from area fire stations on a 24-hour, 7-day basis. Additional ambulance service is available from other local city fire departments through the mutual aid agreements (Section 8.2).

\subsection{UNIFIED DOSE ASSESSMENT CENTER}

The Unified Dose Assessment Center (UDAC) is the technical extension of the DOE-RL-EMT, providing services to both the DOE-RL-EMT and the ECCS. The primary mission of the UDAC is to provide recommendations for protective actions, dose calculations and projections, and consultation in the area of industrial hygiene for hazardous substances, biology, environmental monitoring, and meteorology to support the DOE-RL-EMT and the ECCs.

Industrial hygiene and biological consultants at the UDAC advise and assist in determining proper response procedures for spills or releases of toxic, flammable, carcinogenic, and pathogenic materials. The UDAC personnel are responsible to provide a central unified assessment of the dispersion and impact of environmental releases from the Hanford Facility. In communication with the ECC, UDAC coordinates the assessment of impacts and assists in the determination of actual and potential release scenarios.

\subsection{HANFORD PATROL/BENTON COUNTY SHERIFF}

The Hanford Patrol serves as the security agency for the Hanford Facility. The Benton County Sheriff's Department provides law enforcement for the Hanford Facility. In the event of an emergency, the Hanford Patrol provides services such as activating the crash alarm systems or area sirens, coordinating the movement of emergency responders through security gates, assisting evacuation, establishing barricades, and making necessary notifications through the single point-of-contact. Benton County Deputies will assist with traffic control activities. Agreements al so have been established with the Richland, Kennewick, and Pasco police departments to provide additional backup capabilities if required.

\subsection{ALERTING OF PERSONNEL ON THE COLUMBIA RIVER}

An agreement exists among the DOE-RL, the Washington Public Power Supply System, Benton and Franklin Counties, and the Thirteenth Coast Guard District to ensure safety on the Columbia River during an emergency at the Hanford Facility and to coordinate response activities for alerting personnel on the Columbia River. 
DOE /RL-93-75

Rev. 2

\subsection{METEOROLOGICAL INFORMATION}

An agreement is in place between the DOE-RL and the National Weather Service to define mutual responsibilities for providing meteorological information in an emergency situation. Additional meteorological information can be obtained from the Hanford Site weather station.

\subsection{WASHINGTON PUBLIC POWER SUPPLY SYSTEM}

An agreement has been established between the DOE-RL and Washington Public Power Supply System for providing mutual assistance as needed. This assistance is available in the use of facilities and equipment for personnel decontamination, first aid, evacuation and reassembly areas, respiratory protective equipment, protective clothing, radiological survey equipment, resources for river evacuation, and radiological assistance response. 
DOE/RL-93-75

Rev. 2

This page intentionally left blank. 
DOE/RL-93-75

Rev. 2

\subsection{REQUIRED REPORTS}

Three types of written post-incident reports are required for incidents at the Hanford Facility. These reports are summarized in the following sections.

\subsection{ASSESSMENT REPORT TO ECOLOGY AND GOVERNMENT OFFICIAL OR NATIONAL RESPONSE CENTER}

Immediately following classification of an incident as a WAC 173-303 emergency, as assessment report must be transmitted when the regulatory agencies are notified. This initial assessment report will be submitted by the Emergency Coordinator and must include:

- Name and telephone number of reporter

- Name and Address of facility

- Time and type of incident (e.g., release, fire)

- Name and quantity of material(s) involved, to the extent known

- The extent of injuries, if any; and

- The possible hazards to human health and the environment outside the facility

\subsection{WRITTEN REPORT TO ECOLOGY}

Following an incident that requires implementation of the contingency plan, the Emergency Coordinator must ensure that the time, date, and details of the incident are recorded in the TSD units operating record. Within 15 day of the incident, a written report must be submitted to Ecology by the Emergency Coordinator. The report generated through the DOE-RL reporting system may be used to supplement this written report, but will not be used as a substitute unless Ecology approval is obtained. The 15 day report will be submitted by DOE-RL and must include;

- Name, address, and telephone number of RL contact

- Name, address, and telephone number of the affected TSD unit

- Date, time, and type of incident (e.g., fire, explosion)

- Name and quantity of material(s) involved

- The extent of any injuries if any

- Assessment of any actual or potential hazards to human health or the environment caused by the incident, where this is applicable; 
DOE/RL-93-75

Rev. 2

- Estimated quantity and disposition of recovered material that resulted from the incident

- Cause of the incident

- Description of corrective action taken to prevent reoccurrence of the incident.

\subsection{OCCURRENCE REPORTING}

Under DOE Order 0232.1 an occurrence report is required for incidents occurring at the Hanford Facility involving hazardous substances release, fire, etc. Specific details of this reporting system are found in the DOE order. To summarize, the event is categorized within 2 hours and proper notifications are completed to onsite and offsite agencies to include contractor, DOE, county, and state organizations.

These occurrences are investigated, reported, and analyzed promptly to ensure that effective corrective actions are taken in compliance with contractual and statutory requirements. All such occurrences are recorded in the building manager's $\log$ book, and the $\log$ book is audited to ensure that incidents were reported and handled properly. In the DOE reporting system, three levels of incidents are described, in descending order of severity: emergency, unusual occurrence, and offnormal occurrences.

\subsubsection{Emergency Event Reporting}

An emergency event involves an incident in progress or having occurred that is the most serious occurrence and requires an increased alert status for onsite and, in specified cases, for offsite authorities. There are three classifications associated with emergency events: Alert, Site Area Emergency, and General Emergency. Occurrences are classified into one of the three levels based on real or potential consequences to personnel, facilities, or the environment, both on and off of the Hanford Facility. Current MOUs between the state of Washington and the Hanford Site identify events that would be classified at the stated levels. Emergency events require notification of classification to affected populations.

\subsubsection{Unusual Dccurrence Reporting}

An unusual occurrence is a nonemergency occurrence that has significant impact or potential for impact on safety, environment, health, security, or operations. Generally, these types of events result in release of radioactive or hazardous substances in minor amounts, involve degradation of unit safety systems, result in fatalities, exposures to hazardous or radioactive materials, or significant contamination incidents. 
DOE/RL-93-75

Rev. 2

\section{$1 \quad$ 9.3.3 Offnormal Event Reporting}

An offnormal event is a significant deviation from normal operations that requires categorization and reporting. Hanford Facility management is

5 required to evaluate an event to determine the depth of investigation and

6 level of reporting required. 


\section{DOE/RL $-93-75$}

Rev. 2

This page intentionally left blank. 
DOE/RL-93-75

Rev. 2

\subsection{CONTINGENCY PLAN LOCATION}

Copies of this Plan are maintained at the following locations:

- Each specific Part III TSD unit

- Hanford Fire Department (area fire stations)

- Area Emergency Centers

- Occurrence Notification Center

- The DOE-RL Emergency Operations Center, Federal Building, Richland

- Patrol Operations Center

- Kennewick Police Department

- West Richland Police Department

- Washington State Patrol

- Pasco Fire Department

- Richland Fire Department

- City of Kennewick

- Kadlec Medical Center

- Our Lady of Lourdes Health Center

- Benton County Emergency Management Center

- Franklin County Emergency Management Center

23

- Grant County Emergency Management Center 
DOE/RL-93-75

Rev. 2

1

This page intentionally left blank. 
DOE/RL-93-75

Rev. 2

\subsection{REFERENCES} DOE Order 0232.1 , Occurrence Reporting and Processing of Operations
Information

DOE Order 0151.1 , Comprehensive Emergency Management System

DOE Order 5500.3B, Planning and Preparedness for Operational Emergencies

DOE, 1996, Hanford Facility RCRA Permit Handbook, DOE\RL-96-10, U.S. Department of Energy, Richland, Washington

Ecology, Hanford Facility RCRA Permit (DW Portion), as amended, Washington State Department of Ecology, Olympia, Washington.

NIOSH, 1985, Pocket Guide to Chemical Hazards, National Institute of Occupational Safety and Hea1th, U.S. Department of Health and Human Resources, Public Health Service, Centers for Disease Control, Washington, D.C.

WAC 173-303, Dangerous Waste Regulations, Washington State Department of Ecology, 01 ympia, Washington. 


\section{DOE/RL-93-75}

Rev. 2

This page intentionally left blank. 
DOE/RL-93-75

Rev. 2

\section{DISTRIBUTION}

\section{Number of Copies}

\section{ONSITE}

9

3

1

4

53
U.S. Department of Energy-

Richland Operations office

K. A. Beecher

R. M. Carosino

C. P. Christenson

C. E. Clark

D. T. Evans

J. E. Rassmussen

J. L. Tokarz-Hames

S. J. Veitenheimer

Public Reading Room

Bechtel Hanford, Inc.

V. G. Edens

M. C. Hughes

B. D. Schilperoot

Hanford Environmental Health Foundation S. Mcinturff

H1-77

ICF Kaiser Hanford

B. J. Dixon

B4-20

G4-07

G4-07

S4-56

L6-55

B4-20

4 Pacific Northwest National Laboratory

W. J. Bjorklund

C. A. Rosscup

H. T. Tilden III

Technical Files

P7-72

K4 -35

P7-79

$\mathrm{KI}-11$

Westinghouse Hanford Company

T. A. Anderson

T3-04

R. E. Allen

T3-28

GI -50

S6-65

D. M. Bogen

H6-24

R. C. Bowman

S. L. Camp Jr.

G. B. Carlson

L6-79

G2-06

S2-98

GI-40

S6-30

J. L. Demarest

A3-05 
D0E/RL-93-75

Rev. 2

1

2

3

4

5

6

7
DISTRIBUTION (continued)

Number of Copies ONSITE

Westinghouse Hanford Company (continued)

D. E. Good

H. E. Hager Jr.

S3-97

C. C. Hammack Jr.

$54-60$

D. G. Hamrick

J. C. Hamrick

T2-08

D. R. Herman

S6-15

N2-03

H. G. Humphrey, Jr. Qeterue

J. A. Hunter

W. M. Knight (2)

D. C. Lansing

M. R. Lowery

D. A. Marsh

S. K. Meyer

P. C. Miller

A. G. Miskho

T. P. Morales

M. R. Morton

R. $\mathrm{Ni}$

D. R. Nunamaker

R. D. Pierce

D. R. Pyze1

D. E. Rasmussen

J. A. Remaize

L. W. Roberts

W. E. Ross

D. J. Rowl and

W. Smith

J. S. Stair

S. C. Sutton

R. W. Szelmeczka

W. E. Toebe

E. C. Vogt

D. J. Watson

J. H. Wicks Jr.

D. H. Wicks

Central Files
S2-66

- $15-31$

S3-96

R2-58

B1-03

A3-05

R2-58

N2-04

H6-22

L7-98

R2-77.

S5-07

S4-43

T3-04

T4-04

L4-30

L6-18

L6-40

S5-07

R1-67

T3-28

S2-66

S2-37

T4-06

H6-22

T5-50

X0-41

T4-07

S5-58

A3-88 
D0E/RL-93-75

Rev. 2

\section{DISTRIBUTION (continued)}

Number of Copies

ONSITE

Westinghouse Hanford Company (continued)

Facility Operating. Record

H6-08

Hanford Area Fire Station \#1

Hanford Area Fire Station \#2

$\times 3-97$

S3-97

Hanford Area Fire Station \#3

L7-97

Hanford Area Fire Station \#4

N1-97

Document Processing Center

Information Release Administration

A3-94

Occurrence Notification Center

$\mathrm{RI}-08$

Patrol Operations Center (Deputy Chief)

$A 0-20$

Unclassified Document Control

\section{OFFSITE}

1

Tom Corley

Our Lady of Lourdes Health Center

520 N. Fourth Ave.

Pasco, WA 99301

1

Greg Garcia

Pasco Fire Department

404 W. Clark St.

Pasco, WA 99301

1 Mark Harden

Kennewick Police Department

741 S. Dayton St.

Kennewick, WA 99336

1 Terry Hobbs, Depart Director

Benton County Emergency Management Center

P. 0. Box 6144

Kennewick, WA 99336

$1 \quad$ Bob Kelly

City of Kennewick

P. 0. Box 6108

Kennewick, WA 99336

1

Sam Lorenz, Director

Grant County Emergency Management Center

P. 0 . Box 37

Ephrata, Wa 98823

1

Mike Noski

West Richland Police Department

3805 W. Van Giesen St.

West Richland, WA 99353

Distr-3 
DOE/RL-93-75

Rev. 2

\title{
DISTRIBUTION (continued)
}

\author{
Number of Copies \\ OFFSITE (continued) \\ 1 Susan Pryce, Safety officer \\ Kad7ec Medical Center \\ 888 Swift BTvd. \\ Richland, WA 99352 \\ 1 \\ John Scheer, Director \\ Frankl in County Emergency Management Center \\ 502 Boeing St. \\ Pasco, WA 99301 \\ 1 Lt. David Trunkey \\ Washington State Patrol \\ Route 7, Box 12450 \\ Kennewick, WA 99337 \\ 1 \\ Craig Williamson \\ Richland Fire Department \\ 1000 George Washington Way \\ Richland, WA 99352
}

